\title{
HOMELAND SECURITY AND THE RUSSIAN APPROACH
}

\section{Lionel PONSARD}

\begin{abstract}
Homeland security remains a vague notion in the Russian understanding, but essentially refers to the safeguard of key national interests, the struggle against global threats, with a strong focus on international terrorism, and eventually the fight against transnational organized crime. Homeland security tasks are usually performed in the Russian Federation by several security agencies distributed among three different ministries, i.e. the Interior Ministry, the MOD, and the Ministry for Civil Emergencies (EMERCOM). However, this trilateral structure is perhaps not sufficient to ensure concrete results in Russia's attempts to fight against organized crime. Although having repeatedly stated the need to re-establish the rule of law, the current Russian government appears to deal with oligarchs in a discretionary way. It would therefore be rather utopian to expect any real improvement without a radical change of attitude from the top leadership. Russian approach towards homeland security is rather close to the European standards in terms of structural implementation, but much closer to the U.S. approach in terms of response and the preference for the use of force. The analysis of Russia's security concepts demonstrates that security threats to the country are assessed as having clearly increased in the last ten years. A gloomier worldview combined with a reduced influence on the international scene obviously calls for more assertive security documents. In the same logic, the Russian perception advocates force as the preferred solution to deal with asymmetric threats, such as international terrorism. This became even more apparent in the wake of the 11 September attacks on the United States and the renewed strategic partnership between Moscow and Washington. The recognition of Russia's key role in the fight against international terrorism did indeed bring Russia back into the Western security community. On the Russian side, the Russian leadership soon understood that Russia was too weak to counter these new threats on its own and would lose any prospective benefit by openly confronting the West.
\end{abstract}

Keywords: Homeland Security, Asymmetric Threats, Russian Transnational Organized Crime, Russia's Security Concepts.

One of the most difficult issues facing governments today is the question of how to address new threats to national security. Gone are the days of the Cold War when intelligence agencies dealt essentially with a conventional threat that was rather pre- 
dictable. These new threats have become increasingly global and asymmetric, following no rules or expected timelines. These observations suggest that these non-traditional threats pose risks to all countries including Russia. Needless to say that these threats would better be defeated through a coordinated and collaborative response among states. And yet, all countries do not see themselves "at war" against these new amorphous threats. ${ }^{1}$ As a consequence, Europeans, Americans and Russians do not necessarily perceive the struggle against transnational threats in the same way. Interestingly enough, the widely held belief in the United States that force is the preferred solution to deal with transnational threats such as terrorism does find some echo among the Russian people. It is even commonly admitted that the odd couple of Bush and Putin was brought dramatically nearer by the terrorist assault. To grasp the Russian perception of these new threats, we will first explore some definitions pertaining to the concept of "homeland security," with a particular focus on their practical implementation in the Russian ministerial structures. We will then look into domestic threats of transnational nature, in particular criminal activities also defined as "organized crime." But in the Russian view, homeland security also includes the fight against global external threats. In order to better apprehend Russia's current perception of outside threats to its national security, we will review the evolution of Russia's security concepts. This analysis will also be put in parallel with Russia's position on the international scene in the aftermath of September 11. In so doing, a number of traditional security parameters and concerns will be highlighted.

\section{Homeland Security Concepts and Russian Practice}

"Homeland security" remains a rather vague concept, but basically suggests a security against an ill-defined threat or enemy. ${ }^{2}$ The various components of homeland security notably include vital national interests, counterterrorism, counter proliferation, and international crime. The task of securing the homeland is most often described by European equivalents such as "domestic" or "internal" security. We should note however that the U.S. Department of Homeland Security strongly differs from a typical European ministry of the interior. Most important, the Department of Homeland Security essentially focuses on dealing with the threat posed by catastrophic terrorism, while the responsibilities and the tasks of a European ministry of the interior are much broader and include most if not all of a state's law enforcement elements. As for Russia, "Homeland security" essentially refers to the protection of national interests, the fight against global threats such as international terrorism, and eventually the fight against transnational organized crime. In practice, most of the functions of the American Department of Homeland Security are actually spread across a range of ministries in Russia. First and foremost, the Ministry of the Interior of Russia (MVD) heads the system of the bodies of internal affairs (police forces) and internal troops (equivalent to the French gendarmerie) and has jurisdiction over public administra- 
tion in the sphere of protection of the rights and liberties and law enforcement. ${ }^{3}$ In the aftermath of the Beslan tragedy, the Russian Interior Ministry has taken over a larger security role. Its new responsibilities now include the control of an additional 440 sites throughout the Russian Federation, many of which are viewed as potential targets for terrorists. Such reforms aim obviously at enhancing Russia's protection against terrorist actions. ${ }^{4}$ Apart from the Interior Ministry, the Ministry of Defense and the Ministry of the Russian Federation for Civil Defense, Emergencies and Elimination of Consequences of Natural Disasters (also called EMERCOM) are also responsible for homeland security tasks. The Russian MOD controls all military activities including the operational control of the army on a daily basis, but also retains a monopoly on military information and military intelligence. Last but not least, EMERCOM directs the whole Civil Defense apparatus, including Civil Protection Troops. These troops are armed with specialized equipment, such as engineering, medical, radiation, chemical and biological protection. ${ }^{5}$ However, this trilateral structure is perhaps not enough in order to ensure an incremental improvement to Russia's internal security and its efforts in combating transnational threats such as organized crime.

\section{Russia's Fight against Transnational Organized Crime}

There has been a major increase in organized crime in the Russian Federation since the disintegration of the Soviet Union. The collapse of the Communist Party removed former mechanisms of social, political, and economic control and created a very permissive environment for criminal enterprise. The transition to the market economy was also made without any well-established rules or regulations. We might identify several major kinds of criminal activities, including drug trafficking, arms trafficking, trafficking in nuclear material, human trafficking, and money laundering. These activities are transnational since it is clear that the Russian Mafia has also spread its activities to other countries. ${ }^{6}$

Russian organized crime poses a direct threat to security at a national and international level. Internally, it challenges the state by providing a rival authority structure ready to use violence in order to enforce its actions. It also infiltrates and eventually corrupts public and private officials in order to neutralize law enforcement resources. The aim is usually to prevent any governmental initiative designed at fighting criminal groups. Organized criminal groups also try to invest in the potential of economies in transition. By disrupting social and economic institutions, they encourage inflationary pressures and undermine economic equilibrium. Furthermore, the implementation of a black economy inevitably affects economic growth. Most important perhaps, the people might opt for a hard-line government that promises to restore order. In this kind of scenario, the potential for a reversal of the trend towards democratiza- 
tion and the reinforcement of autocratic tendencies is very considerable. Externally, it penetrates territories without respecting the sovereignty of national borders. While these threats are of great concern in Russia itself, the failure to deal with transnational organized crime from a global perspective merely provides further opportunities for their growth and development. Therefore, the international community should find ways to cooperate in preventing the expansion of the phenomenon of Russian organized crime.

In these circumstances, Russia has initiated more stringent measures against organized crime and the different ministerial security agencies have engaged in more comprehensive and effective inter-state cooperation. Different studies have been conducted and aim at understanding the conditions that are conducive to the rise and growth of transnational criminal organizations. However, there is so far no guarantee for success although the current government has often announced the return of the rule of law. The fact is that legislative power is united with executive power in the person of President Putin. The power over the life and liberty of the citizens is arbitrary since the judge is also the legislator. ${ }^{7}$ Oligarchs and other typhoons currently are part of this strategy aiming at centralizing the maximum amount of power. They have a certain marge de manoeuvre as long as they respect some basic principles such as the absence of any real ambition in the realm of domestic politics. Khodorovsky tried to play this risky game. He finally lost and has recently been sentenced to 9 years in prison. Problems such as organized crime also provide the Kremlin with additional arguments that require the ceding of more liberties. Indeed, for the time being, most of the Russians are happy to cede more power and freedoms to the government. It is of major significance that in the view of most experts, Russia always appeared to have a low view of human nature, always believed in strong leadership, and always put primary reliance on coercion and repression orchestrated by the ruling administrative elite. Obviously, better coordination between security agencies remains fundamental, but we might also draw some parallel between the decision to strengthen security structures, the need to safeguard national interests, and the evolution of Russia's security concepts.

\section{The Evolution of Russia's Security Concepts}

On 21 April 2000, President Putin signed a decree approving a New Military Doctrine. The document, which replaces the one approved by former president Yeltsin in 1993, is a revised version of the blueprint published in the official Defense Ministry newspaper Krasnaya Zvezda on 9 October 1999. In this document, the military security of the Russian Federation rests upon strategic, political and economic factors. Therein, the threats to the security of the country are assessed as hav- 
ing clearly increased since 1993. The document also refers to the expansion of military blocs and alliances as detrimental to Russia's military security. ${ }^{8}$

In sum, the New Doctrine reflects a gloomier and more militarized worldview than the previous one. This more assertive doctrine can be regarded as a reaction to the continuing decline of Russia's standing in international politics. This is particularly apparent in the paragraph addressing the lowering of the deployment threshold of nuclear weapons, which states that "the Russian Federation reserves the right to use nuclear weapons in response to an attack on itself or its allies by nuclear weapons or other weapons of mass destruction, and also in response to large scale attack by conventional weapons in situations critical to the national security of the Russian Federation." $"$ This new nuclear policy can also be found in the New National Security Concept ${ }^{10}$ approved by president Putin on 10 January 2000 in replacement of the National Security Concept ${ }^{11}$ signed by president Yeltsin in December 1997. While recognizing that the threat of large-scale aggression against Russia in the foreseeable future is practically absent, the document underlines that Russia has to conduct its policy from a position of relative weakness. In other words, the weakening of the Russian Federation justifies the repositioning of the nuclear aim as the only guarantee of security. ${ }^{12}$

In this context, nuclear deterrence becomes the most important task of the Russian armed forces. One of the major changes in Russia's declared nuclear posture is probably the reconsideration of the long disregarded option of nuclear first strike. ${ }^{13}$ However, the new nuclear policy does not define clearly the use of nuclear weapons, nor does it specify whether nuclear weapons are to be considered instruments of warprevention or war-fighting. ${ }^{14}$ Indeed, according to the New National Security Concept, "all forces and facilities available, including nuclear weapons, will be used if necessary to repel armed aggression, if all other means of resolving the crisis have been exhausted or have proved to be ineffective." In the 1997 version of the National Security Concept, this article read differently: "Russia reserves the right to use all forces and means at its disposal, including nuclear weapons, in case an armed aggression creates a threat to the very existence of the Russian Federation as an independent sovereign state." This means that nuclear weapons are no longer reserved solely for extreme situations as in the event of a threat to Russian national survival, but can also potentially be used in a small-scale war that does not necessarily threaten Russia's existence. These formulations thus show that Russia tries to compensate its conventional weakness by moving beyond a nuclear doctrine based exclusively on deterrence.

In both documents, military force is still presented as by far the most relevant instrument of power in international relations. As a consequence, the level and posture of the military potential of the state is to be enhanced to a sufficiently high level. Thus, 
while the 1993 Military Doctrine mainly consolidated the view of Russia as a regional hegemon, the New Military Doctrine and the New National Security Concept both reflect a consensus on the imperative to preserve Russian interests on issues of vital strategic concern and to re-assert the Russian position on the international scene.

\section{Russia's Fight against Global Threats after September 11}

The terrorist attacks on the United States demonstrated once for all that no single entity - state or organization - could address these new threats to security and that their defeat required a coordinated response among states. In particular, the Russian leadership was very much aware of the fact that Russia was too weak to counter all these threats on its own and to achieve its long-term goals by openly confronting the West. Joining the West in the global campaign against transnational threats was therefore a sort of survival strategy at a time when the country had to concentrate on its domestic economic revival. Russia had neither the means to nor the interest in engaging into a very costly foreign and security policy and direct rivalry with the West. Only a sound economy would permit Russia to rebuild its military power necessary to the conduct of a realist policy aimed at rehabilitating the country's status on the international scene. The 11 September 2001 terrorist attacks on the United States thus brought about a shift in both Russian and Western policies, which were both conducive to greater rapprochement and interaction in the struggle against international terrorism.

From the outset, Russia actively and positively participated in the anti-terrorist coalition, not only providing diplomatic support to the campaign, but also sharing intelligence on sources and methods used to finance terrorist groups, and applying sanctions against the countries harboring terrorists. This cooperation gave rise to frank exchanges on the entire spectrum of the terrorist threat-including the risk of nuclear, biological and chemical proliferation-and included joint exercises addressing the consequences for the civilian population of a large-scale terrorist attack. When the United States initiated a campaign against the Taliban and Al-Qaida in Afghanistan, ${ }^{15}$ Moscow opened Russian airspace to US planes and enhanced military assistance to the Northern Alliance. ${ }^{16}$ Considering Russia's key role and military experience in Central Asia and Afghanistan, its participation was paramount to the success of the coalition against terrorism and the post-11 September international order. ${ }^{17}$ Indeed, Russia's endorsement of U.S. Operation "Enduring Freedom" facilitated the provision of practical support by the former Soviet Central Asian states. Furthermore, reluctant states like China, India, and Iran finally decided to follow the Russian stance and to offer political support.

No need to say that this support and Putin's strongly pro-western rhetoric soon faced criticism amongst Russian political and military representatives, ${ }^{18}$ as well as within large sections of the public. Apparently, many did not share his "confidence in the 
American and European commitment to reward Moscow for its support." ${ }^{, 19}$ In their perception, the US still viewed Russia as an obstacle to its interests in a number of issues: missile defense $;^{20}$ NATO enlargement; spread of US influence in Central Asia; relations with rogue states like Iraq, Iran, North Korea, etc. They also wanted Putin to avoid repeating the mistakes of Gorbachev and Yeltsin who had made concessions to the West and received very little in return. ${ }^{21}$ Their position was further reinforced by severe U.S. blows to Russian interests on issues of vital strategic concern: U.S. withdrawal from the ABM Treaty and NATO's expansion to the East. In addition, the prospect of a long-term US military presence in the near abroad Central Asia was strongly opposed, not least by the Russian military.

Putin's decision to maintain a pro-Western line was in fact a way of showing that Russia belonged to the same security community. In other words, the attacks on the U.S. helped Russia to complete the building of what is now named the "threat bridge to the West." 22 By embarking on the campaign, Russia succeeded in imposing itself on the post-11 September order. The very recognition of common security concerns with the West, and shared vulnerability to threats such as global terrorism-and more particularly Sunni Islamist extremism - was another reason that comforted Putin in his decision. The fact that the U.S. were so preoccupied with building an international anti-terror coalition in which Russia ought to play a central role improved seemingly Russia's chances to regain some influence in international politics and to be treated as an almost equal partner by the US administration.

Indeed, the success of the U.S. operation against the Taliban in Afghanistan largely depended on the position of Russia, both in terms of its possible participation in the coalition and with regard to its influence on such neighboring countries as Tajikistan, Kyrgyzstan, and Iran. Not only does Russia possess military bases and units in the area close to the Afghan theatre, and does exert strong influence on at least some of the local Central Asian regimes (Tajikistan), but it also has strong personal interest in containing the Taliban threat. ${ }^{23}$ Given its tense relations with Iran and Pakistan, Washington could hardly dispense with Russian facilities in the region. For its part, Russia's strategy was dictated by the perspective of several benefits.

A major benefit for Moscow included the Western endorsement of Russia's war in Chechnya ${ }^{24}$ and the recognized legitimacy of this official anti-terrorist campaign. ${ }^{25}$ Many Western political representatives soon put the Chechen rebels on par with organizers of 11 September attacks. ${ }^{26}$ In this context, the West took up a new attitude towards Russia, and this change has confirmed, in the eyes of the Russian public, that the Russian policy in Chechnya, for example, has been a right one. Of course, Western human rights campaigners had expressed their concern about a softening of criticism towards the conduct of Russia's military operations in Chechnya. ${ }^{27}$ 
Another important element was Russia's desperate need for Western investment. Although Russian economy recovered rapidly from the massive rouble devaluation of August 1998 - largely due to high oil and gas prices - there was still a strong need for further economic reform and restoring international investors' confidence in the Russian market. In return for its cooperation in the fight against terrorism, Putin expected U.S. and European support for Russia's economy. In this context, the importance of oil and energy resources did not go unnoticed in Russia's decision to join the anti-terrorist coalition. Indeed, the campaign against terrorism in Central Asia risked placing Russia as an alternative and a more reliable source of energy to the West. In other words, while not expecting short-term economic or political benefits from its cooperation with the West, Russia could expect future western investments and gains from the sale of oil and gas to the West, and could then potentially dominate its main Arab competitors - who were definitely more reluctant than Russia to join the antiterror coalition - on the global energy market. Among the Russian people, however, there was widespread resignation and disillusionment regarding any Western support for Russia's economic difficulties.

We should bear in mind that, in so acting, Russia did not look at democracy and market economy as goals per se, but the best available instruments in making the Russian state stronger and more efficient. By becoming a member of the western community through cooperation against global threats, Russia would be able not only to save money the country would otherwise have spent on building a strategic parity or at least a credible and sufficient anti-western defense. Russia's choice meant a significant departure from traditional Soviet and - to a very large extent-post-Soviet thinking on Russia's place in the international system. In other words, it implied the end of Primakovian policies designed at counterbalancing the western influence by building strategic anti-western alliances with alternative centers of power in a multipolar world.

\section{Conclusion}

Russia's land stretches across both Europe and Asia. Its immensity provides the country with natural strategic interests throughout Europe, the Middle East, the Indian subcontinent, and the Far East. ${ }^{28}$ However, this immensity was also the cause of scores of invasion of the Russian territory, from the Mongols to Napoleon to the Nazis. At the same time, it is a country whose brutal weather has often repelled these same foes with equal power. At the end of the Soviet Union, the loss of superpower status and the sudden emergence of new states on Russia's periphery were sources of considerable unease and confusion. ${ }^{29}$ This post-imperial frustration was exacerbated by the fact that Russia's position with respect to a number of traditional security parameters - such as access to the high seas and availability of critical resources, etc.- 
had significantly deteriorated with the disintegration of the former USSR a decade ago. In Russia's security documents, the motives of the West with respect to NATO enlargement, Kosovo, or missile defense were-at least implicitly - condemned and as a consequence, the level and posture of the military potential of the state was to be enhanced to a sufficiently high level.

The changing security environment following the 11 September 2001 attacks on the United States presented an unprecedented opportunity for Russia, not only to review its partnership with the West, but also to recognize their interdependence concerning the safeguard of vital security needs that none can meet alone. Both sides had good geopolitical reasons to cooperate at least at the outset. Obviously, it is fairly easy to misinterpret the changes of the Russian position by disregarding crucial nuances. Indeed, it should be observed that, regardless of what has been the real motivation of President Putin and his team, the main trend in the wider discourse has been not towards greater solidarity with the United States and the West as a whole, but about a re-assertion of the Russian position on the international stage.

While Russia's perception of Homeland security undoubtedly includes the fight against external threats and the safeguard of national interests, it also refers to domestic threats, in particular organized criminal activities. Russia, especially in its larger metropolitan areas, always had "big city" crime problems. In the Soviet period, however, crime was hidden and repressed by a totalitarian regime. Beginning in the mid-1980s, criminal activity became more visible with the arrival of perestroika and its associated political, social, and economic reform. These circumstances were then exacerbated by the diminished standards of living that came with the wholesale economic changes in post-Cold War Russia. At a state level, the interplay between organized crime and government officials is nothing short of subversion of the Russian state itself. This would obviously require immediate and decisive action at the highest levels of the executive, legislative, and judicial branches of the Russian government. However, experts tend to believe that one man only currently exercises these three powers in Russia and uses oligarchs to his own benefit. Obviously, more coordination among the different security agencies is also paramount, but no major improvement can be expected without a radical change of attitude from the top leadership.

\section{Notes:}

1 John L. Clarke, "Securing the European Homeland," Journal of Homeland Security (September 2003): 1.

2 Chris Seiple, "Homeland Security Concepts and Strategy," Orbis 46, no. 2 (Spring 2002): 259-273. 
3 See the official site of the Ministry of the Interior of Russia, <http://eng.mvdrf.ru>.

${ }^{4}$ Roger McDermott, "Russian Interior Troops Expand Security Role," Eurasia Daily Monitor 1, no. 146 (14 December 2004).

${ }^{5}$ See the official site of EMERCOM, <http://emercom.gov.ru〉.

${ }^{6}$ Phil Williams and Ernesto Savona, The United Nations and Transnational Organized Crime (London: Frank Cass, 1996), 16.

7 Charles de Secondat, Baron de Montesquieu, The Spirit of Laws (Cambridge: 1995), 157.

${ }^{8}$ See inter alia Henrikki Heikka, Beyond the Cult of the Offensive. The Evolution of Soviet/Russian Strategic Culture and its Implications for the Nordic-Baltic Region (Helsinki: The Finnish Institute of International Affairs, 2000), 79.

9 See "Voyennaya Doktrina Rossii" (Russia's Military Doctrine), Rossiyskie Vesti, no. 224, 18 November 1993. For the New Military Doctrine, see "Voyennaya Doktrina Rossiyskoy Federatsii" (Military Doctrine of the Russian Federation), Rossiyskaya Gazeta, 25 April 2000. For the Draft of the New Military Doctrine, see "Voyennaya Doktrina Rossiyskoy Federatsii" (Military Doctrine of the Russian Federation), Krasnaya Zvezda, 10 September 1999. See also Vladimir Yermolin, "Military Signs a New Doctrine," Izvestiya, 13 October 1999; Andrey Korbut, "Draft Military Doctrine," Nezavisimaya Gazeta, 13 October 1999; and V. Chugunov, "We Discuss the Draft Military Doctrine. With Consideration for the Potential of the Country," Krasnaya Zvezda, 19 October 1999.

${ }^{10}$ The text may be found at the official site of Russia's Security Council, <www.scrf.gov.ru> See also Nezavisimoye Voyennoye Obozreniye, 14 January 2000.

${ }^{11}$ See National Security Concept of the Russian Federation, <http://www.acronym.org.uk/ $43 \mathrm{nsc} . \mathrm{htm}>$. See also "New Look at National Security Concept," Rossiyskaya Gazeta, 6 October 1999.

${ }^{12}$ See Viktor N. Pavliatenko, "Russian Security in the Pacific Asian Region. The Dangers of Isolation," in Russia and East Asia. The $21^{\text {st }}$ Century Security Environment, eds. Gilbert Rozman, Mikhail G. Nosov, and Koji Watanabe (New York: M. E. Sharpe, East West Institute, 1999), 20.

${ }^{13}$ See Andrei V. Zagorski, "Traditional Russian Security Interests in the Caucasus and Central Asia. Perceptions and Realities," in Russia, the Caucasus, and Central Asia. The $21^{\text {st }}$ Century Security Environment, eds. Rajan Menon, Yuri E. Fedorov, and Ghia Nodia (New York: M. E. Sharpe, East West Institute, 1999), 62.

${ }^{14}$ See Heikka, Beyond the Cult of the Offensive. The Evolution of Soviet/Russian Strategic Culture and its Implications for the Nordic-Baltic Region, 82.

${ }^{15}$ Moscow supported UNSC resolution 1373 which in effect endorsed the US military action against the Taliban.

${ }^{16}$ It is important to note that Russia viewed Afghanistan under the Taliban rule as an acute source of destabilization in the region and a key exporter of Islamic terrorism to Chechnya. From 1996, Russia was the main supplier of military support to the Northern Alliance, and provided it with large quantities of weapons and war equipment in the aftermath of 11 September.

${ }^{17}$ Anatol Lieven, "The Secret Policemen's Ball: The United States, Russia and the International Order after 11 September," International Affairs 78, no. 2 (2002), 245-259.

${ }^{18}$ This confrontational stance was mainly advocated by Vladimir Zhirinovsky, leader of the Liberal Democratic Party LDPR (nationalist extremist); and Gennady Zyuganov, leader of the communist party KPRF. 
${ }^{19}$ Oksana Antonenko, "Putin's Gamble,” Survival 43, no. 4 (Winter 2001-2002): 49-60.

${ }^{20}$ From a Russian perspective, the building of more substantial defenses on the U.S. side would erode Russia's deterrent and pose serious impediments to further reductions in missiles (cf. START agreements).

${ }^{21}$ See Lieven, “The Secret Policemen's Ball: The United States, Russia and the International Order after 11 September."

${ }^{22}$ Boris Piadyshev, "After the Terrorist Attacks," International Affairs (Moscow) 47, no. 5 (2001), 6.

${ }^{23}$ See Jakub M. Godzimirski, 11 September 2001 and the Shift in Russia's Policy towards NATO (Oslo: The Norwegian Atlantic Committee, Security Policy Library, 7-2002), 13.

${ }^{24}$ We should bear in mind that Putin's popularity and his political ascension were based on his uncompromising stance regarding the conflict in Chechnya.

${ }^{25}$ See Nodari Simonia and Vladimir Baranovsky, "What is in Store for the World," International Affairs (Moscow) 48, no. 1 (2002), 15.

${ }^{26}$ NATO Secretary General Lord Robertson, for instance, in his interview published in Russia on the day of the Rome Summit, described the Chechen rebels as a branch of the global terrorist network.

${ }^{27}$ See Antonenko, "Putin's Gamble."

${ }^{28}$ George Vernadsky, A History of Russia (New Haven: Yale University Press, 1961), 10.

${ }^{29}$ See also Joseph L. Nogee and R. Judson Mitchell, Russian Politics: The Struggle for a New Order (Boston: Allyn and Bacon, 1997), 163.

LIONEL PONSARD is currently a Research Advisor at the NATO Defense College in Rome. He first studied at the Universities of Louvain and London, and earned his $\mathrm{PhD}$ in Political Science at the University of Leiden. Dr. Ponsard started his professional career as an Assistant Lecturer at the University of Namur, Belgium. In 1999, he joined the Belgian Ministry of Defense as a Political Adviser. He later held several management positions at the Belgian General Staff, mainly in the area of political, security and defense issues related to the former Soviet Union and traveled extensively to the region. He was at the time mainly responsible for the preparation and the follow-up of bilateral and multilateral cooperation programs with eastEuropean countries, particularly in the field of Defense reform. During his assignment, he also worked as Belgian Representative for specific NATO Economic, Political and Military Committees. On the academic side, he was Lecturer at the Belgian Royal Military Academy and the Belgian Royal Institute for Defense Studies. Dr. Ponsard is regularly invited to lecture at different academic institutions such as the National Defense University in Washington, the Russian Academy of Science in Moscow, the University of Louvain, the University of Namur, the NATO School, the NATO Studies Centre in Bucharest, the Ukrainian Military Academy, the Belgian Royal Military Academy, and the Belgian Royal Institute for Defense Studies. He is member of different associations such as the Belgian Association for Political Science and the Belgian Institute for International Relations. He has also published a number of articles in English, French, and Russian on post-Soviet issues and transatlantic relations in different academic journals including the NATO Review. Dr. Ponsard is perfectly fluent in no less than six foreign languages including Russian. 